\section{CARME GREGORI, RAMON X. ROSELLÓ (EDS.), L'EMPREMTA DEL MITE EN LA LITERATURA DEL PRIMER TERÇ DEL SEGLE XX. BARCELONA: PUBLICACIONS DE L’ABADIA DE MONTSERRAT 2018}

El volum col·lectiu L'empremta del mite en la literatura del primer terç del segle XX és el fruit del treball d'un grup d'investigadors que col-laboren en el marc del projecte de recerca La literatura de segundo grado: las relaciones hipertextuales en la literatura catalana desde el "Modernismo" hasta el 1939, segons llegim en el pròleg de Carme Gregori i Ramon X. Roselló, editors del llibre. I tal com anuncia ja el mateix títol del projecte, el volum està dedicat monogràficament a l'estudi de fenòmens que es produeixen durant el procés de reescriptura literària dels mites. En el llibre, dividit en dues parts titulades respectivament "Mites clàssics" i "Mites bíblics i mites populars", s'han recollit dotze articles que aporten una reflexió sobre la presència dels mites i les estratègies de la seva recreació en la literatura catalana de principis del segle passat.

El concepte de la literatura de segon grau que apareix en el títol del projecte suggereix també el marc conceptual de què parteixen els autors dels estudis, formulat per Gérard Genette a Palimpsestes. La littérature au second degré (1982). Efectivament, en el conjunt dels treballs presentats en el volum, la proposta de Genette ha servit de base teòrica per dur a terme les anàlisis, en algun cas hàbilment completada o desenvolupada amb referències a les aportacions d'altres investigadors (Riffaterre, Rialland, Jauss, etc.). Aquest marc metodològic únic i coherent permet considerar el volum com una unitat -una característica no gaire freqüent en el cas dels llibres col·lectius, sigui dit de passada-i, sobretot, en possibilita una lectura global, que desvela punts comuns i divergències entre les estratègies $i$ els procediments aplicats en els textos analitzats en diferents estudis; així mateix, en definitiva, permet situar aquests textos en una mena de xarxa per tal de copsar unes tendències generals en la reescriptura dels mites en la literatura catalana del primer terç del segle XX.

Dit això, cal subratllar que el volum pot ser considerat a diferents nivells que resulten complementaris; cadascun d'ells ens proporciona reflexions força estimulants al voltant de la relació entre la literatura i el mite. En el primer, ens trobem davant d'una sèrie d'estudis dedicats a examinar els objectius i les estratègies d'utilització del mite en els textos d'una quinzena d'autors, entre els quals hi ha tant les figures més destacades de la literatura catalana, com d'altres potser menys conegudes. Formen la (impressionant) nòmina: Prudenci Bertrana, Pere Calders, Josep Carner, Adrià Gual, Joan Maragall, Alfons Maseras, Joan SalvatPapasseit, Santiago Rusiñol, Carles Riba, Diego Ruiz, Josep Maria de Sagarra, Joan Santamaria, Carles Soldevila, Francesc Trabal i Llorenç Villalonga. En les contribucions recollides en 
aquest volum es presenten anàlisis realitzades amb rigor, que destaquen per la seva solidesa i aporten unes reflexions importants i summament interessants sobre les relacions transtextuals entre les obres tractades i els mites que els han servit d'hipotext. Mereix un esment especial el treball de contextualització que els autors dels estudis executen amb molta cura i que permet treure a llum les implicacions socials, politiques, econòmiques i ideològiques de la reescriptura dels mites en el primer terç de la centúria passada. És, sens dubte, un valor afegit del volum, el qual, així mateix, no només permet comprendre millor el fenomen de la recreació dels mites i el seu funcionament en els textos comentats en els articles, sinó que, considerat en conjunt, també ofereix una visió àmplia i diversificada de la literatura catalana de principis del segle XX, centrada en la problemàtica de l'ús, la persistència $i$, al capdavall, l'indubtable atractiu del mite. En aquest sentit, val a dir que la uniformitat estructural dels articles, la majoria dels quals comença amb la presentació del context historicoliterari en què es van gestar els textos que, més endavant, són objecte d'examen, facilita la lectura i el seguiment del conjunt. Per aquesta raó el llibre resultarà útil no només als especialistes, que hi trobaran estudis aprofundits i força ben documentats que tracten autors i textos concrets, sinó també a tots aquells que volen fer-se una idea global de les vicissituds i de la dinàmica del desenvolupament de la literatura catalana en un dels moments crucials de la seva història que, a més, s'emmarquen en una xarxa de fenòmens culturals i literaris entrelligats, tant en l'àmbit català com europeu.

Aquestes consideracions ens porten a destacar un segon nivell en què es poden considerar els articles recollits per Carme Gregori i Ramon X. Roselló. Llegits en conjunt, formen un esbós del panorama general de la presència del mite en les lletres catalanes de principis del segle XX, entenent-lo en els diferents sentits assenyalats en els títols dels apartats. I encara que el monogràfic no proporcioni una visió exhaustiva d'aquesta problemàtica, ni tampoc ho pretengui, sí que aporta una sèrie de dades rellevants i observacions força suggeridores que poden servir com a punt de partida per oferir tal panorama. En particular, els estudis aplegats en el volum demostren que, en el període considerat, la literatura catalana recorre d'una banda al mite, que representa la tradició i la continuïtat, i, de l'altra, s'afanya a trencar amb aquesta tradició i aquesta continuïtat, tot procurant ressemantitzar els mites a la recerca d'una modernitat extrema. En definitiva, l'excitació d'allò més modern, la prova de la qual són el tramvia en els versos de Maragall o el metro en la poesia de Salvat-Papasseit, resulta més evident i palpable quan troba un contrapunt en el mite (en aparença) immutable. En el rerefons d'aquest diàleg intens entre la tradició i la contemporaneïtat, entre el passat i el present, entre l'ahistoricitat i el temps històric, es va configurant, potser, un nou arrelament en el mite, més autoconscient, més crític, que, d'altra banda, també permet apreciar degudament la importància de determinants procediments i estratègies de reescriptura, com ara la ironia. En aquest sentit, la lectura dels articles dona al lector una visió penetrant de la literatura catalana d'aquella època, de les seves expectatives i dels seus objectius, així com de la recerca de les bases de la seva identitat.

Ara bé, tant per a l'escriptor com per al lector -incloent-hi la categoria específica del lector que alhora és crític o estudiós- el fet d'entrar en diàleg amb el mite implica saber copsar i aprofitar la seva polisèmia i riquesa, que poden manifestar-se de diferents maneres: en la coexistència de diverses variants d'un mateix mite, que en alguns casos obre la porta a lectures diverses del relat mític, fins i tot dispars; en reelaboracions literàries, que formen la història d'un mite literaturitzat; $o$, finalment, en l'existència d'uns mites literaris capaços de 
generar noves obres literàries. Els autors dels estudis que formen el recull identifiquen casos de totes tres categories, $\mathrm{i}$ en destaquen la diversitat d'usos en les lletres catalanes del primer terç del segle XX. Així mateix, situen la literatura catalana d'aquell període en tota una xarxa intertextual de relats mítics i les seves versions i reelaboracions efectuades en diferents moments històrics, cultures i literatures: des de la Creació bíblica fins als mites moderns o llegendes populars com la Belle et la Bête, la femme fatale, el Mal Caçador o el comte Arnau, tot passant per històries del món clàssic: les d'Ulisses, Penèlope, Níobe, Fedra, Prometeu, Medea... En alguns casos, aquesta posada en perspectiva permet observar relacions transtextuals complexes o inesperades entre diferents sistemes literaris, que s'illuminen els uns als altres, en un apassionant joc de miralls.

Finalment, en un nivell més general, el volum convida a reflexionar sobre la supervivència dels mites en les literatures i les cultures, sobre la necessitat de tornar-hi -inevitable, sembla-, d'entrar en un inacabable diàleg amb la tradició, la prova del qual són les contemporanitzacions del mite, alhora que també sobre les seves reformulacions, qüestionaments o fins i tot degradacions i rebuigs; també incita a preguntar-se sobre les raons de les transformacions que sofreix el mite en diferents contextos culturals, lingüístics, polítics, econòmics o ideològics. En aquest context, val a dir que el lector trobarà en el llibre la bibliografia bàsica sobre la teoria del mite i el concepte d'hipertextualitat, disseminada en diferents articles, que li podrà servir de guia en les seves recerques personals i així mateix augmentar l'inqüestionable profit que es pot treure de la lectura d'aquest volum.

Barbara Łuczak

Uniwersytet im. Adama Mickiewicza w Poznaniu 